\title{
One-Dimensional Network of Zinc(II) Coordination Polymer with $4,4^{\prime}$-Bipyridine $\left(4,4^{\prime}\right.$-bipy)
}

\author{
Jungsook Kim, Uk Lee, ${ }^{\dagger}$ and Bon Kweon Koo* \\ Department of Chemistry, Catholic University of Daegu, Gyeongbuk 712-702, Korea. "E-mail: bkkoo@cu.ac.kr \\ 'Department of Chemistry, Pukyong National University, Busan 608-737, Korea \\ Received April 12, 2006
}

Key Words : Zn(II)-4,4'-bipy coordination polymer, Crystal structure

The design and synthesis of novel coordination architectures are of great interest in coordination chemistry and solid-state chemistry. The field of crystal engineering using bridging organic amine ligands with transition metals to form coordination polymers continues to be interesting due to their many applications, both actual as well as potential. ${ }^{1}$ The 4,4'-bipy ligand and its analogues have been used in much of this work. ${ }^{2}$ The coordination polymers bearing 4,4'bipy ligands have been shown to form a wide range of interesting network topologies, for example, chains, ladders, grids, and adamantoid networks, ${ }^{3}$ and 4,4'-bipy as bifunctional ligand has a great of advantages for the construction of porous organic-inorganic hybrid solids: (a) it has a long spacer that allows for constructing microporous materials with large cavities or channels; (b) it possesses straight connection modes that will lead to infinite ladder or grid architectures; (c) it has a strong capability of hydrogen bonding that plays an important role in the assembly of supramolecular compounds. Based on this strategy, despite the thousands of structure already reported with 4,4'-bipy, we focus to extend the yet undiscovered structural variety of M-4,4'-bipy systems.

In this work, we report on a new zinc coordination polymer assembled using 4,4'-bipyridine as a spacer ligand and acetate anion, namely $\left[\mathrm{Zn}_{2}(\mathrm{OAc})_{4}\left(4,4^{\prime} \text {-bipy }\right)_{2}\right]_{\mathrm{n}}(\mathbf{1})$.

\section{Experimental Section}

Synthesis of $\left[\mathrm{Zn}_{\mathbf{2}}(\mathrm{OAc})_{\mathbf{4}}\left(\mathbf{4 , 4} \mathbf{4}^{\prime}-\mathrm{bipy}\right)_{2}\right]_{\mathbf{n}}$ (1). A solution of $\mathrm{Zn}(\mathrm{OAc})_{2} \cdot 2 \mathrm{H}_{2} \mathrm{O}(0.182 \mathrm{~g}, 0.83 \mathrm{mmol})$ in ethanol $(15 \mathrm{~mL})$ was added to a solution of 4,4'-bipy $(0.130 \mathrm{~g}, 0.83 \mathrm{mmol})$ in $\mathrm{CH}_{2} \mathrm{Cl}_{2}(2 \mathrm{~mL})$. The colorless crystals which formed over a $24 \mathrm{~h}$ period were filtered off and dried in vacuo. Yield 62\% (0.172 g). Anal. Calc. for $\mathrm{C}_{14} \mathrm{H}_{14} \mathrm{~N}_{2} \mathrm{O}_{4} \mathrm{Zn}$ : C, 49.51; H, 4.15; N, 8.25. Found: C, 49.17; H, 4.10; N, 8.19. IR (KBr pellet, $\mathrm{cm}^{-1}$ ): $3074(\mathrm{~m}), 3043(\mathrm{~m}), 3003$ (w), 2924 (w), 1604 (s), $1487(\mathrm{~m}), 1432(\mathrm{~s}), 1333(\mathrm{~m}), 1218(\mathrm{~m}), 1066(\mathrm{~m}), 1043$ (m), $1005(\mathrm{~m}), 817$ (s), $730(\mathrm{~m}), 625(\mathrm{~s}), 467(\mathrm{~m})$.

X-ray crystallography. Structural measurement for the compound was performed on a STOE STADI $4^{4}$ four-circle diffractometer using graphite monochromatized Mo-K $\alpha$ radiation $(\lambda=0.71069 \AA)$ at $298(2) \mathrm{K}$. The unit cell parameters were calculated by least-squares fit of 59 reflections in the ranges of $9.5<\theta<10.5^{\circ}$. Intensities of three reflections monitored periodically exhibited no significant variation. The structure was solved by direct method $^{5}$ and refined on $\mathrm{F}^{2}$ by full-matrix least-squares procedures. ${ }^{6}$ All non-hydrogen atoms were refined using anisotropic thermal parameters. Hydrogen atoms were included in the structure factor calculation at idealized positions by using riding model, but not refined. Crystal data for $\mathrm{C}_{28} \mathrm{H}_{28} \mathrm{~N}_{4} \mathrm{O}_{8} \mathrm{Zn}_{2}$ : triclinic, $\mathrm{P}-1, Z=1, a=8.088(1), b=9.190(1), c=$ 10.676(1) A, $\alpha=109.70(1), \beta=100.03(1), \gamma=101.78(1)^{\mathrm{o}}, V$ $=703.5(10) \AA^{3}, \mu=1.757 \mathrm{~mm}^{-1}, R_{1}=0.0278, w R_{2}=0.0732$ based on 3223 reflections with $I \geq 2 \sigma(I)$, Largest peak and hole $=0.428$ and $-0.338 \mathrm{e}^{-3}$.

\section{Results and Discussion}

The ORTEP drawing of the compound with atom labeling is shown in Figure 1(a). The extended structure (Fig. 1(b)) contains linear chains formed by 4,4'-bipy ligands connecting $\mathrm{Zn}$ atoms $(\mathrm{Zn}-\mathrm{Zn}$ distance $=11.502(1) \AA)$. $\mathrm{Zn}$ atoms $(\mathrm{Zn}-\mathrm{Zn}$ distance $=3.961(6) \AA)$ in parallel Zn-bipy-Zn chains are bridged by acetate groups to form double chains. All $\mathrm{Zn}$ atoms are octahedrally coordinated through four oxygen atoms $(\mathrm{Zn}-\mathrm{O}(\mathrm{av})=2.127(2) \AA)$ of acetate groups and two nitrogen atoms from two $\mu$-4,4'-bipy ligands ( $\mathrm{Zn}-\mathrm{N}$ (av) $=$ 2.195(2) $\AA$ ). The $\mathrm{Zn}-\mathrm{N}$ bond distances are similar to those found in related $\mathrm{Zn}(\mathrm{II})-4,4^{\prime}$-bipy coordination polymers. ${ }^{7}$ Based on the overall charge considerations, the oxidation states of zinc atoms are +2 . The bond angles about the zinc centers indicate considerable deviation from regular octahedral geometry. Acetate groups coordinate to the zinc atoms in two different ways. One anion type uses two oxygen atoms to chelate to a zinc ion forming a fourmembered $\mathrm{Zn}-\mathrm{O}-\mathrm{C}-\mathrm{O}$ ring. The other anion type forms a bridge using two oxygen atoms between the zinc centers in two parallel linear chains. The $\mathrm{Zn}-\mathrm{O}$ bond lengths (2.027(2) and 2.012(2) A) for the bridging oxygen atoms, which are 


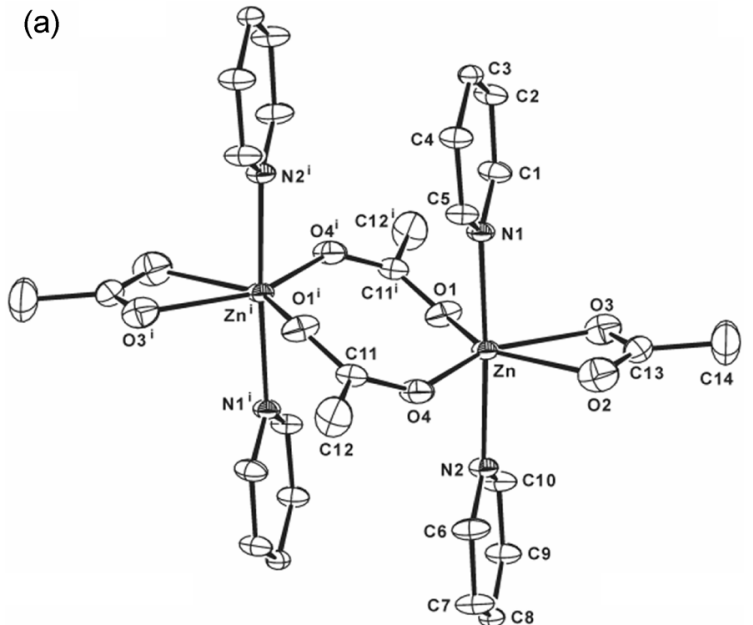

(b)

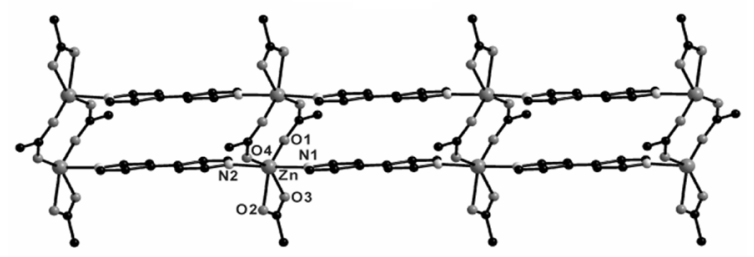

(c)

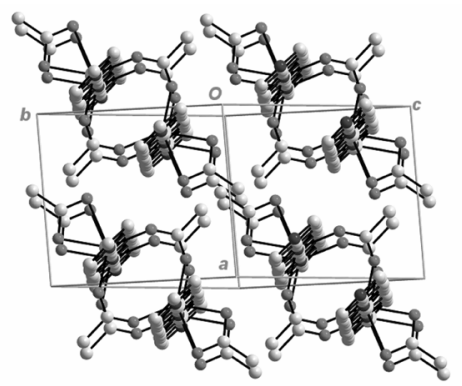

Figure 1. (a) ORTEP view of $\mathbf{1}$ with atomic labeling at $30 \%$ thermal ellipsoids. Hydrogen atoms are not shown for clarity. (b) View of the one 1-D double-chain created by the bridging acetates. (c) Perspective view along the c-axis. Selected bond lengths $(\AA)$ and angles $\left({ }^{\circ}\right)$ : $\mathrm{Zn}-\mathrm{O}(1)=2.027(2), \mathrm{Zn}-\mathrm{O}(2)=2.299(2), \mathrm{Zn}-\mathrm{O}(3)$ $=2.171(2), \mathrm{Zn}-\mathrm{O}(4)=2.012(2), \mathrm{Zn}-\mathrm{N}(1)=2.189(2), \mathrm{Zn}-\mathrm{N}(2)=$ $2.200(2), \mathrm{O}(1)-\mathrm{C}(11)^{i}=1.250(3), \mathrm{O}(4)-\mathrm{C}(11)=1.247(3), \mathrm{O}(2)-$ $\mathrm{C}(13)=1.232(3), \mathrm{O}(3)-\mathrm{C}(13)=1.252(3), \mathrm{C}(11)-\mathrm{C}(12)=1.500(3)$, $\mathrm{C}(13)-\mathrm{C}(14)=1.488(4), \mathrm{O}(4)-\mathrm{Zn}-\mathrm{O}(1)=123.70(8), \mathrm{O}(4)-\mathrm{Zn}-\mathrm{O}(3)$ $=147.50(8), \mathrm{O}(1)-\mathrm{Zn}-\mathrm{O}(3)=88.61(7), \mathrm{O}(4)-\mathrm{Zn}-\mathrm{O}(2)=90.70(7)$, $\mathrm{O}(1)-\mathrm{Zn}-\mathrm{O}(2)=145.47(8), \mathrm{O}(3)-\mathrm{Zn}-\mathrm{O}(2)=56.88(7)$, Symmetry code i: $-\mathrm{x}, 2-\mathrm{y}, 1-\mathrm{z}$.

similar to those found in related $\left[\left\{\mathrm{Zn}(\mu \text {-OAc })_{2} \mathrm{Zn}\right\}(\mu\right.$ bpe $\left.)_{3}\right]_{n}\left(\mathrm{ClO}_{4}\right)_{2 \mathrm{n}}{ }^{8}$ are shorter than the $\mathrm{Zn}-\mathrm{O}$ bond lengths involving the chelating oxygen atoms. The bond distances between the chelating oxygen atoms and the zinc center are 2.171(2) and 2.299(2) $\AA$, which are similar to those of $\left[\mathrm{Zn}(\mathrm{OAc})_{2}\left(\mathrm{H}_{2} \mathrm{O}\right)_{2}\right] .^{9}$ The most interesting structural feature is that 1-D Zn-bipy-Zn subunits are inter-connected through acetate groups to generate a double chain structure with an unprecedented chair type of an eight-membered $\{\mathrm{Zn}-\mathrm{O}-\mathrm{C}-$ $\mathrm{O}_{2}$ metallocycle (Fig. 1(c)). In contrast, a number of metal(II) coordination polymers of $\mathrm{Co}, \mathrm{Ni}, \mathrm{Cu}, \mathrm{Zn}$, and $\mathrm{Cd}$, based on 4,4'-bipy and different bridging bis-bidendate liagnds such as nitrate, perchlorate, sulfate, phosphate, etc. have been reported. ${ }^{10-14}$ However, the compound with the double chain structure by the 4,4'-bipy and acetate anion is rare $^{8,12}$ and to our knowledge is the first example of zinc compund in which acetate anion act as chelating and bridging ligand.

IR spectrum includes bands in the range over $2854 \mathrm{~cm}^{-1}$ correspond to the stretching vibrations of $\mathrm{C}-\mathrm{H}$ groups, and the bands in the range $1640-1333 \mathrm{~cm}^{-1}$ were associated with the pyridine ring stretching vibrations. In the infrared spectrum, the two very strong bands at 1604 and $1432 \mathrm{~cm}^{-1}$ could be due to $v_{\text {asy. }}(\mathrm{COO})$ and $v_{\mathrm{sy}}(\mathrm{COO})$ vibrations of acetate group. ${ }^{9}$

TG analysis was carried out under a flow of nitrogen atmosphere in the range from 0 to $800{ }^{\circ} \mathrm{C}$ using heating rate of $10{ }^{\circ} \mathrm{C} \mathrm{min}^{-1}$. The TGA curve exhibited a one-step weighloss mechanism. The complex undergoes a significant weigh loss of $79.05 \%$ (calcd. $80.74 \%$ ) in the temperature ranges of 97-270 ${ }^{\circ} \mathrm{C}$, implying that two acetate groups and 4,4'bipyridine may be lost synchronously. The total observed weigh losses of $79.05 \%$ for the compound assume that the final residue is elemental metal $\mathrm{Zn}$.

In conclusion, a new inorganic-organic hybrid solid $\left[\mathrm{Zn}_{2}(\mathrm{OAc})_{4}\left(4,4^{\prime} \text {-bipy }\right)_{2}\right]$ was obtained by reacting $\mathrm{Zn}(\mathrm{OAc})_{2}$. $2 \mathrm{H}_{2} \mathrm{O}$ with 4,4 '-bipy in a ethanol/ $\mathrm{CH}_{2} \mathrm{Cl}_{2}$ solvent system. The structure of the compound contains linear double $\mathrm{Zn}$ bipy-Zn chains bridged by acetates in which the acetate groups coordinate to the $\mathrm{Zn}$ atoms in two different ways, that is, four-membered $\mathrm{Zn}-\mathrm{O}-\mathrm{C}-\mathrm{O}$ ring as chelating and eightmembered $\{\mathrm{Zn}-\mathrm{O}-\mathrm{C}-\mathrm{O}\}_{2}$ ring as bridging ligands.

Supplementary materials. Crystallographic data for the structural analysis have been deposited with the Cambridge Crystallographic Data Center (Deposition No. CCDC290063). These data can be obtained free of charge at www.ccdc.cam.ac.uk/conts/retrieving.html (or from the Cambridge Crystallographic Data Centre, 12, Union Road, Cambridge CB2 1EZ, UK; Fax: +44-1223/336-033; E-mail: deposit@ccdc.cam.ac.uk).

\section{References}

1. (a) Mahata, P.; Natarajan, S. Eur. J. Inorg. Chem. 2005, 2156. (b) Rao, C. N. R.; Natarajan, S.; Vaidhyanathan, R. Angew. Chem. Int. Ed. 2004, 43, 1466. (c) Zaworotko, M. J. Chem. Commun. 2001, 1. (d) Batten, S. R.; Robson, R. Angew. Chem. Int. Ed. 1998, 37, 1461. (e) Chen, Z. N.; Fu, D. G.; Yu, B. K.; Tang, W. X. J. Chem. Soc. Dalton Trans. 1994, 1917. (f) Real, J. A.; Munno, G. De.; Munoz, M. C.; Julve, M. Inorg. Chem. 1991, 30, 2701. (g) Fujita, M.; Kwon, Y. J.; Washizu, S.; Ogura, K. J. Am. Chem. Soc. 1994, 116,1151

2. (a) Roesky, H. W.; Andruh, M. Coord. Chem. Rev. 2003, 236, 91. (b) Ma, B. Q.; Sun, H. L.; Gao, S.; Xu, G. X. Inorg. Chem. 2001, 40, 6247. (c) Wen, Y. H.; Cheng, J. K.; Feng, Y. L.; Zhang, J.; Li, Z. J.; Yao, Y. G. Inorg. Chim. Acta 2005, 358, 347. (d) Huang, S. D.; Xiong, G.; Sotero, P. H. J. Solid State Chem. 1998, 138,361 .

3. (a) Wu, C.-D.; Lu, C.-Z.; Wu, D.-M.; Zhuang, H.-H.; Huang, J.-S. Inorg. Chem. Commun. 2001, 4, 561. (b) Yaghi, O. M.; Li, H. L.; 
Davis, C.; Richardson, D.; Groy, T. L. Acc. Chem. Res. 1998, 31, 478.

4. STOE STADI4, X-RED \& X-SHAPE, X-ray structure evaluation package; STOE-Cie Gmbh: Hilpertstrase 10, D64295, Darmstadt, Germany, 1996.

5. Sheldrick, G. M. Acta Cryst. 1990, A46, 467.

6. Sheldrick, G. M. SHELXS97-2 and SHELXL97-2; University of Göttingen: Göttingen, Germany, 1997.

7. (a) Tao, J.; Tong, M. L.; Chen, X. M. J. Chem. Soc. Dalton Trans. 2000, 3669. (b) Tong, M.-L.; Cai, J.-W.; Yu, X.-L.; Chen, X.-M.; Ng, S. W.; Mak, T. C. W. Aus. J. Chem. 1998, 51, 637. (c) Tong, M.-L.; Ye, B.-H.; Cai, J.-W.; Chen, X.-M.; Ng, S. W. Inorg. Chem. 1998, 37, 2645.

8. Morsali, A.; Abedini, J. Inorg. Chem. Commun. 2005, 8, 460.

9. Ishioka, T.; Shibata, Y.; Takahashi, M.; Kanesaka, I.; Kitakawa, Y.; Nakamura, K. T. Spectrochimica Acta 1998, A54, 1827.

10. (a) Wagner, B. D.; McManus, G. J.; Moolton, B.; Zaworotko, M. J.
Chem. Comm. 2002, 2176. (b) Barnett, S. A.; Blake, A. J.; Champness, N. R.; Nicolson, J. E.; Wilson, C. J. Chem. Soc. Dalton Trans. 2001, 567. (c) Barnett, S. A.; Champness, N. R. Coord. Chem. Rev. 2003, 246, 145. (d) Fletcher, A. J.; Cussen, E. J.; Prior, T. J.; Rosseinsky, M. J.; Kepert, C. J.; Thomas, K. M. J. Am. Chem. Soc. 2001, 123, 10001.

11. Yaghi, O. M.; Li, H.; Groy, T. L. Inorg. Chem. 1997, 36, 4292.

12. Lu, J.; Yu, C.; Niu, T.; Paliwala, T.; Crisci, G.; Somosa, F.; Jacobson, A. J. Inorg. Chem. 1998, 37, 4637.

13. Chen, C.-Y.; Lii, K. W.; Jacobson, A. J. J. Solid State Chem. 2003, $172,252$.

14. (a) Zhu, L. G.; Kitagawa, S. Inorg. Chem. Commun. 2003, 6, 1051. (b) Lindroos, S.; Lumme, P. Acta Crystallogr. 1990, C46, 2039. (c) Lo, S. M.-F.; Chui, S. S.-Y.; Shek, L.-Y.; Lin, Z.; Zhang, X. X.; Wen, G.-H.; Williams, I. D. J. Am. Chem. Soc. 2000, 122, 6293. (d) Lu, J.; Crisci, G.; Niu, T.; Jacobson, A. J. Inorg. Chem. 1997, 36, 5140 . 